\title{
T.U. Dzhakipova
}

Kazakh Humanitarian Law Innovative University, PhD Doctoral student
(Republic of Kazakhstan, Semeycity), tdzhakipova@ mail.ru

\section{HISTORY OF FORCED RESIDENCE IN EASTERN KAZAKHSTAN IN THE $1930 \mathrm{~s}$.}

\begin{abstract}
This articleis dedicated the first deportation of the Polish people to Kazakhstan after political changes in the country, including the first arrival of Poles in East Kazakhstan. The process of resettlement of Germans and Koreans, as well as Poles began in 1930. Especially majority of immigrants in Kazakhstan were Koreans. Besides, it is written about the history of the German and Polish peoples, who were first deported to Kazakhstan from Ukraine and Russia. The article is based on the growth of German settlements in the Akmola, Semey, Pavlodar, Omsk and Barnaul regions at the beginning of the XXth century. The repressions of 1937-1938 had a special impact on the socio-demographic development of the population of the East Kazakhstan region. The local population has decreased, but the population growth has occurred at the expense of other nationalities. In the article, based on extensive archival materials, the author introduces the history of the peoples who migrated to the Semipalatinsk and East Kazakhstan regions in 1930. The composition of the displaced peoples and nationalities is analyzed. Employment in the national economy of East Kazakhstan, social policy of local authorities in relation to migrants and their relationship with the local population were considered. The demographic situation of the region's population during the famine of the 1930s was recorded using archival documents and periodicals, scientific research.
\end{abstract}

Keywords: East Kazakhstan, politics, organization, nation, border, population, region, ethnos, deportation, migration.

\section{Т.У. Джакипова}

Қазақ инноващиялық гуманитарлық-заң университетінің PhD докторанты
(Қазақсттан Республикасы;; Семей қ.), tdzhakipova@ mail.ru

\section{ШЫҒЫС ҚАЗАКСТАНДАҒЫ 1930 ЖЫЛДАРДАҒЫ КУШТЕП ҚОНЫС АУДАРТУ ТАРИХЫ АЯСЫНДА}

\section{Aң̧датпа}

Бұл мақалада поляктардың Қазақстандағы алғашқы саяси қоныс аударуларынан кейін, елдегі саяси өзгерістерден, соның ішінде поляктардың Шығыс Қазақстанға алғашқы келуінен кейін болды. Немістер мен корейлерді, сондай-ақ поляктарды қоныстандыру процесі 1930 жылы басталды. Әсіресе Қазақстанға көшіп келгендердің көбі корейлер болды. Сонымен қатар, Қазақстанға алғаш рет Украина мен Ресейден жер аударылған неміс және поляк халықтарының тарихы туралы жазылған. Мақала XX ғасырдың басында Ақмола, Семей, Павлодар, Омбы және Барнаул облыстарындағы немістердің қоныстануының өсуіне негізделген. 1937-1938 жылдардағы қуғын-сүргін Шығыс Қазақстан облысы тұрғындарының әлеуметтік-демографиялық дамуына ерекше әсер етті. Жергілікті халық азайды, бірақ халықтың өсуі басқа ұлттардың есебінен болды. Мақалада кең архивтік материалдарға сүйене отырып, автор 1930 жылы Семей және Шығыс Қазақстан облыстарына қоныс аударған халықтардың тарихымен таныстырады. Қоныс аударылған халықтар мен ұлттардың құрамы талданады. Шығыс Қазақстанның халық 
шаруашылығындағы жұмыспен қамту, мигранттарға қатысты жергілікті биліктің әлеуметтік саясаты және олардың жергілікті тұрғындармен қарым-қатынасы қарастырылды. Мұрағат құжаттары мен мерзімді басылымдарды, ғылыми зерттеулерді қолдану арқылы 1930 жылдардағы аштық кезіндегі аймақ тұрғындарының демографиялық жағдайы тіркелді.

Кілт сөздер: Шығыс Қазақстан, саясат, ұйым, ұлт, шекара, халық, аймақ, этнос, депортация, көші-қон.

\section{Джакипова Т.У.}

\section{PhD докторант Казахского инновационного гуманитарно-юридического университета (Республика Казахстан; Семей), tdzhakipova@mail.ru}

\section{В ИСТОРИИ ПРИНУДИТЕЛЬНОГО ПРЕБЫВАНИЯ В ВОСТОЧНОМ КАЗАХСТАНЕ В 1930-Х ГГ.}

\section{Аннотация}

Эта статья написана после первой политической миграции поляков в Казахстан, политических изменений в стране, в том числе первого прибытия поляков в Восточный Казахстан. Процесс переселения немцев и корейцев, а также поляков начался в 1930 году. Большинство иммигрантов в Казахстан были корейцами. Кроме того, написана история немецкого и польского народов, впервые депортированных в Казахстан из Украины и России. В основе статьи - рост немецких поселений в Акмолинской, Семипалатинской, Павлодарской, Омской и Барнаульской областях в начале XX века. Репрессии 1937-1938 годов оказали значительное влияние на социально-демографическое развитие населения Восточно-Казахстанской области. Коренные народы сократились, но рост населения был обусловлен другими странами. В статье на основе обширных архивных материалов автор представляет историю народов, переселившихся в Семипалатинскую и ВосточноКазахстанскую области в 1930 году. Анализируется состав перемещенных народов и наций. Рассмотрены вопросы занятости в народном хозяйстве Восточного Казахстана, социальная политика местных властей по отношению к мигрантам и их отношения с местным населением. С помощью архивных документов и периодических изданий, научных исследований зафиксировано демографическое положение населения региона во время голода 1930-х годов.

Ключевые слова: Восточный Казахстан, политика, организация, нация, граница, население, регион, этнос, депортация, миграция.

Introduction: The history of the period in question was one of the most difficult periods of the early twentieth century. The history of deportation in this period is especially studied by domestic historians. Exploring new pages of the history of the former totalitarian state will remain one of the key issues today. The totalitarian system took the lives of millions of people and turned to a new channel. The dark history of this period can be divided into two parts: one is the persecution and expulsion of intellectuals, and the other is the history of deportation. These two difficult histories were deeply rooted in Kazakhstan. In these turbulent times, the demographic situation was supplemented by settlers from other countries. Since the recognition of Kazakhstan as a sovereign state, great changes have taken place in the science of history. It is known that due to the demographic situation, many documents kept secret in the archives have been published and are now being studied and become one of the most important topics. As part of the article, a study of ethno-demographic issues in the eastern part of the country was conducted.

Materials and methods: In determining the methodological basis of the research, several methods of studying social phenomena and trends were used. In the study of the problem in 
historical science, the study was guided by the comparison of real facts and evidence through archival and newspaper and magazine materials, research. In addition, the research used general scientific, philosophical, sociological, historical research methods, such as analysis, analysis and generalization, historical-comparative, system-structural, theoretical knowledge, modeling and typification. Basically, the theoretical basis of the topic and the methodology of the research are considered in the main dissertation. The method of comparative research of press materials and archival documents and research materials is widely used in the reporting of historical events or political situations.

Discussion of results: It is important to consider the research of the Soviet system in solving the problem of ethno-demography in Kazakhstan. General migration issues Nusupbekov, M.Kh.Asylbekov, SB Nurmukhamedov, BN Abisheva, NG Pan, etc. Some statistical and archival materials that identify ethno-demographic processes in Kazakhstan are included in his works.

The history of ethno-demographic processes in Kazakhstan, changes in the age, gender, ethnic and social composition of the population, demographers M.Kh. Asylbekov and AI It is considered in the works of Kudaibergenova. The authors analyze the arrival of other ethnic groups in the country, its impact and changes on the demography of Kazakhstan, as a result of which ethno-demographic development trends. Focuses on the political events and circumstances that influenced the various changes of the people of Kazakhstan in the 1930s.

The results of the study: In the 1930s of the 20th century, the foreign policy of the Soviet Union was between two fronts. One of them was militaristic Japan and the other was Germany. The aggressive Hitler government intended to invade the USSR through Poland.

The Far East posed a military threat to the Soviet Unionbefore Germany. Their goal was to capture the Far East lands and some parts of Siberia of the Soviet government.Since 1934 the work of the Japanese reconnaissance services in the Soviet Union has increased threefold. There were seven consulates of legal reconnaissance in the Far East and Siberia. According to the International Economic Agreement, Japanese workers and employees worked in transport and fisheries offices in Sakhalin, Vladivostok. In 1936 the motives of Japanese scouts were revealed.

A Japanese military mission was created near the Soviet border in the Far East by order of the Kwantung Army headquarters, which was an intelligence center. Its leaders were based in Harbin and had 13 residences in Mudanjiang, Hongchun and Minanda.[1]

Poles, Germans, Koreans, Chechens and Ingush were deported to Kazakhstan in the late 1930s. On the 5-6 January in 1937 the All-Union Population Census was held. In fact, the census began in September 1932 and was carried out in several districts of Moscow. However, the census was postponed to 1935, and then to 1936. According to scientists the census was planned several times. For example, from the point of view of V.G. Volkova the census was postponed at least four times. According to the 1937 All-Union Census, the population of the USSR was $162,039,470$ people. The next census of 1939 counted 170,557,093 people. [2]

According to the table of the collection "Materials for the series" peoples of the Soviet Union "in 1937 the population of USSR was 156948 597, and in 1939 - 161434707 people lived there. As shown in the collection, the population of Kazakhstan in 1937 was 4929254 people, and in 1939 - 5217085 people. [3]

In general, according to the All-Union census шт 1939 the Kazakh land was inhabited by representatives of this people even before the forced settlement. As reported by the census, the population of Kazakhstan differs by ethnicity.

As stated in the situation after the repressions, in 1939 there were 116,087 Kazakhs in the East Kazakhstan region, 369,796 Russians, 27,253 Ukrainians, 5400 Tatars, and 4041 Germans.page135.

In consonance withAlekseenko's research, in 1939 the total number of other nationalities was 431 thousand people, including 137 thousand Kazakhs, 201 thousand Russians, 42 thousand Ukrainians, 15 thousand Germans and 36 thousand people of other nationalitiesin East Kazakhstan [4]. 
The first deported people to Kazakhstan were Poles. The issue of relocating them from their territory to the internal countries arose after a mutual agreement between Poland and Germany in 1934. There was a reason. The forcibly deported Poles were placed to the Ukrainian border. There were also partial clashes and conflicts between local Ukrainians and Poles. Moreover, the number of opponents of the Soviet system has increased. The Soviet government issued two decrees on the resettlement of Poles from the border to Kazakhstan.One of them was the decree of January 23, 1936 "On resettlement from the Ukrainian SSR to the Kazakh SSR", and the other - the decree of April 26, 1936 "On economic support of the Kazakh SSR from the USSR to the Karaganda region. "[5].

In April 1936, it was decided to deport about 45 thousand people from the Ukrainian border to Kazakhstan. 35,739 Poles (99.8\%) were sent to Kazakh lands and settled in the northern regions.[6]

Due to unrest situations on the western border, Poles continued to be resettled to the territory of the Soviet Union in subsequent years. In December 1939, the Soviet government approved the "Regulations on the employment of special settlers from the western regions of the USSR and the USSR. "Pursuant to this Order People's Commissar of Internal Affairs L. Beria provided 55 railway carriages for transportation.

The deportees ("Siege") were mainly former Polish officers who served in the police and administrative bodies of Poland.

In 1939 Germany's Hitlerite War with the West and the conquest of Poland forced thousands of Poles, soldiers and officers to flee to the Soviet Union. Isolation of border crossings from the border, placement and control within the republics of the USSR were carried out on the basis of special rules. By the census of A. Volkov, 190000 Poles were moved to Kazakhstan. [7]

In the following years, the resettlement of Poles to the border between Ukraine and Belarus began. By the decision of the Council of People's Commissars of the USSR on October 18, 1940, 6681 Poles were deported from these two republics to Kazakhstan [8].

In general, the process of resettlement of Poles and Germans from the Ukrainian border began. Before the forced eviction, about 85 thousand Germans lived in the USSR.[9]

The resettlement of Koreans along the border to the Far East began in 1935. Since 1937 Koreans had been forcibly deported from the Far East to Kazakhstan and Central Asia. In fact, about 200 thousand of Koreans lived in the Amur Region. 20141 Korean families with 95,421 members were brought to Kazakhstan. Most of them were located in Almaty, South Kazakhstan, Aktobe, Kostanay and Karaganda regions. [10] As stated in the plan 14,600 Korean farms had to move to Kazakh lands. [11] However, the number of deported people had been exceeded the plan. As said by historian T. Omarbekov 20789 Korean families, that is 98454 people were deported to Kazakhstanby the February 1938. [12]

Academician M. Kozybaev writes about the political deportees: "In the spring of 1936, the Poles were deported from Ukraine. The following year, Kurds from Azerbaijan and Armenia and 95,000 Koreans from the Far East were settled here. [13]

In general, by the 1939 census in the republic, excluding Kazakhs (2314 thousand) were from other nationalities Russians - 2449 thousand, Ukrainians - 657 thousand, Germans - 93 thousand, Tatars - 107 thousand, Uzbeks - 103 thousand, Belarusians - 31 thousand, Uighurs - 35 thousand, Koreans - 96 thousand, Azerbaijanis - 12 thousand, other minorities nations - 197 thousand. [14] Compared to the census there is a slight difference between the writings of both scientists. If talking about location, the majority of Koreans live in Kyzylorda region. We see this in the archives and in the writings of scientists. Georgy Kan writes about this: "The main place of unloading and temporary resettlement of Koreans in Kazakhstan was the South Kazakhstan region, that part of it, which is now the Kyzylorda region (by the administrativeterritorial division of that time, it was part of the South Kazakhstan region)."

Deportation of Koreans to Kazakhstanhad two stages of resettlement. One of them was the period from the autumn of 1937 to the spring of 1938. The second - from the spring of 1938 continued in 1939. 
The situation at the first stage was very difficult. The Soviet government was not ready to resettle the deportees. Therefore, they had to be placed in palaces, barracks, basements, destroyed mosques and former prisons. These places were not suitable for human habitation. It was difficult to find food for Koreans who lived in the places where were no windows or broken, cold, and not built fireplaces.

It is difficult to see that the population decreased as a result of massive repressions in the USSR in 1937-1938. The same fate befell the deportees of other nationalities.

According to the directive letters of the KGB to the BSEC, the decree of February 14, 1937 "On terrorist, subversive and espionage activities of the German Trotskyists" and on April 2 "On the increasing activity of German intelligence agency and special services in the USSR" were not immediately implemented. This was realized only in the first days of the Great Patriotic War.

The basis for the ethnic cleansing of the Germans was the order of the NKVD of the USSR dated July 25, 1937. 265 Germans were arrested on charges of spying for Germany and belonging to a nationalist fascist organization. This is $3.01 \%$ of the total number of victims of repression in East Kazakhstan. [16]

German opposition to the Soviet government began in the early 1930s. On the official note "about Germans" which was sent to the Kazakh Regional Committee of the CPSU in July 1934, says that in 1929 a massive movement of German emigrantsbegan to the territory of Kazakhstan. Since 1933, when Nazi Germany came to power, a new wave of counter-revolutionary German began secret activities against the Soviets. The process of resistance to the Soviet system in Kazakhstan was carried out through the German consulate in Novosibirsk. Ekaterina Unru, a farmer from the village of Zaborovka, Tsyurupa District, East Kazakhstan region, wrote a letter to the German Baptist Society "Brockhaus": "We are naked, we have to work every day. I do not know the another way, except to say you. It's hard for me to describe all this, I don't know what will happen, I ask you for help". However, the protocol states that the farmer was a member of a collective farm, had a cow, worked more than 200 working days and received enough bread. Similar letters were received from other German settlements in Kazakhstan. [17] At the beginning of the twentieth century, the number of German settlements increased in Akmola, Semey, Pavlodar, Omsk and Barnaul regions. They bought farmland along the railway. Among the settlers were many jewelers, craftsmen and artisans. And the goods which they produced were cheaper and better than local products. However, the Germans did not like the soil of the Kazakh land and the harsh weather. Accustomed to the irrigated fertile lands of inner Russia they asked to return, saying that in the first years the harvest was low. [18] A copy of the protocol of the closed meeting of the Kazraikom Bureau, held on February 25, 1930, negatively assessed the measures taken in all directions as unsatisfactory. In Semey, Akmola, Aktobe, Pavlodar, Petropavlovsk and Ural regions, warnings were issued due to the slow pace of economic and cultural activity in German settlements and the lack of attention to the complete cessation of the immigration process. Noting that the Central Committee will make a number of amendments to the planned activities of the regions. They were instructed to hold re-elections in March-April, translate documents into German and immediately open seven-year German schools. These orders had to be executed immediately and had to submit reports. [19]

So, such a process of opposition to the Bolshevik ideology took place in the following years, when on January 5, 1935, the People's Commissar of Internal Affairs G.G. Yagoda signed a circular from the United State Political Directorate of the People's Commissariat of Internal Affairs, which sets out a new procedure for restoring the rights of labor migrants. It was reported that the massive restoration of the rights of labor migrants who were economically excluded from this circle allowed them to leave their homes. In order to avoid a repetition of such a situation in the future, the issue of preventing mass restoration of rights without the sanction of the KGB of the GULAG, restoration of rights only in settlements, the spread of mass propaganda among them and assistance from economic organizations is being resolved. On January 17, G. Yagoda asked IV Stalin to deprive the immigrants of the right to leave. 
As of July 19, 1935, Kazakhs and people of other nationalities lived in 23 districts of 25 districts and 2 cities of the East Kazakhstan region [21].

According to the 1939 census, most of the population lived in rural areas. However, compared to the 1926 census in 1939, the city's population has tripled. Of these, the part of the urban population in the Semipalatinsk region was 40.6\%, and in the East Kazakhstan region $25 \%[22]$.

Conclusion: The repressions of 1937-1938 significantly influenced the socio-demographic development of the population of the East Kazakhstan region. Due to massive persecution, the local population has declined. However, population growth was accompanied by the deportation of other nationalities. Thus, as a result of the resettlement of other ethnic groups to the Kazakh land, the ethnic composition has been changed.

\section{References:}

1. Khaustov V., Samuelson L. Stalin, NKVD and repression 1936-1938 y. / V. Khaustov, L. Samuelson. - M.: Russian political encyclopedia (RUSSPEN); Fund of the first President of Russia B.N. Yeltsin, 2010. - 432 p. 32-33-p.

2. Sarsekenova K.A.Kazakhstani people in 1920-1930 years. - Almaty: Kazakh University, 2011. - 220 p. - 82, 113-p.

3. Materialsonthe series «Soviet Union's people». Ch. 4. - M., 1990. - p.681.

4. AlekseenkoA.N. Population of Kazakhstan. 1920-1990 y. - Almaty: Science, 1993. - 126 p. 22-p.

5. TanirbergenkyzyL. Historical fate of the Poles in Kazakh land // Star. 1997. - №2. - 195-196- $p$.

6. Volkov A. Poles in Kazakhstan // NOMAD - KAZAKHSTAN. -2006. - №2 (8).

7. Volkov A. Poles in Kazakhstan// NOMAD - KAZAKHSTAN. -2006. - №2 (8).

8. $\quad$ CDMH. DCMH. 1987-s., line 1, case 13. 23-v.

9. AlekseenkoA.N. Population of Kazakhstan. 1920-1990 z2. - Almaty: Science, 1993. -126 c. 18-6.

10. AlekseenkoA.N. Population of Kazakhstan. 1920-1990 z2. - Almaty: Science, 1993. -126 c. 23-6.

11. CDMH. DCMH. 1208-s., line-1, case 47. 217-v.

12. Omarbekov T. Main issues of the history of Kazakhstan in XX centuries. Additional learning supply. - Almaty: «Art», 2003. - 552 p. 303-p.

13. Kozybaev M.K.History's mind (Time flow). 1-book. - Almaty: Science, 1998 - 344 p. 220-p.

14. Asylbekov M.KH., Galiev A.B.Socio-demographic processesin Kazakhstan (1917-1980). - Alma-Ata: Science, 1991. - 192 p. 121-p.

15. Deported people to Kazakhstan: time and fate. - Almaty: «Arys»«Kazakhstan», 1998. - 428 p. 115-p.

16. Materials of international scientific-practical conference «To knowso as not to forget: totalitarian authority and people in the 20-50s of the XX century». 30-31 May of 2014 year. - Ust-Kamenogorsk: «Media-Alyans», 2014. - 577 p. 239-p.

17. CDMH. DCMH. 141-s., 1-t., case 6662. 14-15-v.

18. Vibe P.P.Resettlement of German colonists to the Steppe region at the end of the XIX - beginning of the XX century (for example Akmola, Semipalatinsk provinces) // Materials of international scientific-practical conference: "History of Germans in Central Asia». - Almaty, 1998.- P.19-30

19. From the history of the Germans in Kazakhsatn(1921-1975y). Collection of documents: Archiveof the president of Kazakhstan Republic / Const.: I.N. Bukhonova, T.B.Mitrropolskaya. Almaty: Gotica, 1997. - 376 p. 
20. From the history of deportation, 1930-1935, 667-p.

21. CDMH. DCMH. 141-s., 1-t., case 8302. 27-28-v.

22. Asylbekov M.Kh., Asylbekova Zh.M.The main results of the All-Union Population Census in 1939 in Kazakhstan /Population of Kazakhstan by the All-Union Population Census of 1939. V 5 t. - Almaty: Arys6 2009. - T. 1. - 400 p. 21-p. Пайдаланылван әдебиеттер тізімі:

1. Хаустов В., Самуэлсон Л. Сталин, НКВД және репрессия 1936-1938 жж. / В.Хаустов, Л.Самуэлсон. - М .. орыс саяси энциклопедиясы (RUSSPEN); Ресейдің бірінші президентінің құры Б.Н. Ельцин, 2010. - 432 б. 32-33-б.

2. Сарсекенова К.А. Қазақстан халқы 1920-1930 жж. - Алматы: Қазақ университеті, 2011. - 220 б. - 82, 113-б.

3. «Кеңес Одавының адамдары» сериясының материалдары. 4. - М., 1990. - б.681.

4. Алексеенко А.Н. Қазақсстан халқы. 1920-1990 жж. - Алматы: Ғылылм, 1993 - 126 б. $22-6$.

5. Тәңъірбергенқызыы Л. Поляктардың қ̧азақ жеріндегі тарихи тавдыры // Жұлдыз. 1997. - №2. - 195-196-б.

6. Волков А. Қазақсстандавы поляктар // NOMAD - KAZAKHSTAN. -2006 ж. - №2 (8).

7. Волков А. Қазақсстандавы поляктар // NOMAD - KAZAKHSTAN. -2006 ж. - №2 (8).

8. СDМН. DCMH. 1987 ж., 1-жол, 13-іс. 23-т.

9. АлексеенкоА.Н. Қазақсстан халқ̧ы. 1920-1990 г2. - Алматы: Ғылым, 1993. -126 с. 18б.

10. АлексеенкоА.Н. Қазақ̧стан халқ̧ы. 1920-1990 г2. - Алматы: Fылым, 1993. -126 с. 23-б.

11. СDМН. DCMН. 1208- ж., 1-жсл, 47-іс. 217-m.

12. Омарбеков Т. ХХ васырдавы Қазақустан тарихының негізгі мәселелері. Қосымша оку құральь. - Алматыл: «Өнер», 2003. - 552 б. 303-б.

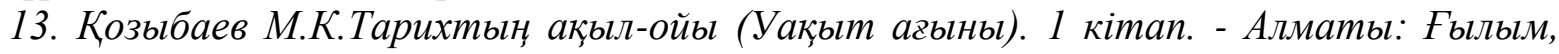
1998. - 344 б. 220-6.

14. Асылбеков М.Х., Галиев А.Б. Қазақстандавы әлеуметтік-демографияльққ прочестер (1917-1980). - Алма-Ата: Ғыльм, 1991. - 192 б. 121-б.

15. Қазақстанва жер аударылzан адамдар: уақыт және тавдыр. - Алматы: «Арыс» «Қазақ̧стан», 1998. - 428 б. 115-б.

16. «Ұмытпау үшін: ХХ васырдың 20-50 жылдарындавы тоталитарльқ билік және адамдар» халықаралық вылыми-практикалық конференщия материалдары. 2014 жылгы 30-31 мамыр. - Өскемен: «Медиа-Алянс», 2014. - 577 б. 239-б.

17. CDMH. DCMH. 141-c., 1-m., Ic 6662. 14-15-m.

18. Vibе Р. Неміс отарлаушыларының ХІХ васырдың аявы - ХХ васырдыңң басында Дала аймавына қоныс аударуы (мысалы, Ақммола, Семей губерниялары) // Хальққаральққ выльлми-практикалық конференция материалдары: «Орталық Азиядавы немістер тарихы» . - Алматы, 1998.- Б.19-30

19. Немістердің Қазақсатндавы тарихынан (1921-1975жж.). Құжаттар жинавы: Қазақсстан Республикасы Президентінің архиві / Конт .: И.Н.Бухонова, Т.Б.Митропольская. Алматы: Готика, 1997. - 376 б.

20. Депортация тарихынан, 1930-1935, 667-б.

21. CDMH. DCMH. 141-c., 1-m., Ic 8302. 27-28-m.

22. Асылбеков М.Х., Асылбекова Ж.М. 1939 жылвы Қазақстандавы Бүкілодақтық хальқ санавының негізгі нәтижелері / 1939 жылвы Бүкілодақтық халық санавы бойынша Қазақ̆стан халқыь. V 5 т. - Алматы: Арыс6 2009. - Т. 1. - 400 б. 21-б. 
